\title{
Acute p38-Mediated Modulation of Tetrodotoxin-Resistant Sodium Channels in Mouse Sensory Neurons by Tumor Necrosis Factor- $\alpha$
}

\author{
Xiaochun Jin and Robert W. Gereau IV \\ Washington University Pain Center and Department of Anesthesiology, Washington University School of Medicine, St. Louis, Missouri 63110
}

\begin{abstract}
Tumor necrosis factor- $\alpha(\mathrm{TNF} \alpha)$ is a proinflammatory cytokine involved in the development and maintenance of inflammatory and neuropathic pain conditions. TNF $\alpha$ can have long-lasting effects by regulating the expression of a variety of inflammatory mediators, including other cytokines and TNF $\alpha$ itself. However, the speed with which TNF $\alpha$ induces tactile and thermal hypersensitivity suggests that transcriptional regulation cannot fully account for its sensitizing effects, and some recent findings suggest that TNF $\alpha$ may act directly on primary afferent neurons to induce pain hypersensitivity. In the present study, we show that peripheral administration of TNF $\alpha$ induces thermal hypersensitivity in wild-type mice but not in transient receptor potential vanilloid receptor TRPV1 ${ }^{-/}$mice. In contrast, TNF $\alpha$ produced equivalent mechanical hypersensitivity in TRPV1 ${ }^{-/-}$mice and wild-type littermates, suggesting a role for TRPV1 in TNF $\alpha$-induced thermal, but not mechanical, hypersensitivity. Because tetrodotoxin (TTX)-resistant $\mathrm{Na}^{+}$channels are a critical site of modulation underlying mechanical hypersensitivity in inflammatory and neuropathic pain conditions, we tested the effects of TNF $\alpha$ on these channels in isolated mouse dorsal root ganglion (DRG) neurons. We report that acute application of TNF $\alpha$ rapidly enhances TTX-resistant $\mathrm{Na}^{+}$currents in isolated DRG neurons. This potentiation of TTX-resistant currents by TNF $\alpha$ is dramatically reduced in DRG neurons from TNF receptor 1 (TNFR1) knock-out mice and is blocked by the p38 mitogen-activated protein kinase inhibitor SB202190 [4-(4-fluorophenyl)-2-(4-hydroxyphenyl)-5-(4-pyridyl)1H-imidazole]. Mechanical hypersensitivity induced by peripherally applied TNF $\alpha$ is also significantly reduced by SB202190. These results suggest that TNF $\alpha$ may induce acute peripheral mechanical sensitization by acting directly on TNFR1 in primary afferent neurons, resulting in p38-dependent modulation of TTX-resistant $\mathrm{Na}^{+}$channels.
\end{abstract}

Key words: pain; MAPK; TNF; nociceptor; DRG; Nav1.8; phosphorylation; sensitization

\section{Introduction}

Tumor necrosis factor- $\alpha(\mathrm{TNF} \alpha)$ is an important proinflammatory cytokine produced by a variety of cell types, including immune, neuronal, and glial cells (Tchelingerian et al., 1993; Wagner and Myers, 1996; Wagner et al., 1998; Schafers et al., 2002; Li et al., 2004). In response to injury or inflammation, TNF $\alpha$ serves as a trigger for activation of other cytokines and growth factors. In addition, TNF $\alpha$ plays a critical role in the development and maintenance of inflammatory and neuropathic pain (Woolf et al., 1997; Junger and Sorkin, 2000; Joseph and Levine, 2004; Sommer and Kress, 2004). For example, TNF $\alpha$-neutralizing agents attenuate thermal hyperalgesia and mechanical allodynia in animal models of neuropathic pain (Lindenlaub et al., 2000; Sommer et al., 2001; Sweitzer et al., 2001), and intraplantar administration of $\mathrm{TNF} \alpha$ produces hypersensitivity to thermal and

Received Sept. 12, 2005; revised Nov. 4, 2005; accepted Nov. 8, 2005.

This work was supported by National Institute of Neurological Disorders and Stroke Grant NS42595 (R.W.G.). We thank the members of the Gereau laboratory for critical comments on this manuscript and C. S. Qiu for assistance with mouse colony maintenance and genotyping.

Correspondence should be addressed to Dr. Robert W. Gereau IV, Washington University Pain Center, Department of Anesthesiology, 660 South Euclid Avenue, St. Louis, M0 63110. E-mail: gereaur@wustl.edu.

DOI:10.1523/JNEUROSCI.3858-05.2006

Copyright $\odot 2006$ Society for Neuroscience $\quad$ 0270-6474/06/260246-10\$15.00/0 mechanical stimuli in rats and mice (Cunha et al., 1992; Perkins and Kelly, 1994; Woolf et al., 1997; Wacnik et al., 2005). However, the mechanisms underlying the behavioral effects of $\mathrm{TNF} \alpha$ are not fully understood.

Although TNF $\alpha$ can have long-lasting effects by regulating the expression of a variety of inflammatory mediators, the rapid onset of $\mathrm{TNF} \alpha$-induced pain hypersensitivity suggests that transcriptional regulation cannot fully account for the sensitizing effects of TNF $\alpha$ (Sommer and Kress, 2004). TNF $\alpha$ applied directly to dorsal root ganglion (DRG) neurons induces mechanical allodynia (Homma et al., 2002; Schafers et al., 2003c), and subcutaneous TNF $\alpha$ increases mechanical sensitivity of C-fibers (Junger and Sorkin, 2000). Furthermore, in vitro perfusion of TNF $\alpha$ to intact or injured DRG elicits neuronal discharges in A- and C-fibers (Liu et al., 2002; Zhang et al., 2002; Schafers et al., $2003 \mathrm{~b}$ ), and application of TNF $\alpha$ to isolated skin enhances heatevoked CGRP release from nociceptor terminals (Opree and Kress, 2000). Many of these effects occur in $<5 \mathrm{~min}$ and are therefore too rapid to be mediated by changes in gene expression. However, the molecular mechanisms underlying these rapid sensitizing effects of TNF $\alpha$ have not been elucidated.

Peripheral sensitization can be induced by modulation of a variety of ion channels that mediate the transduction of thermal 
and mechanical stimuli or regulate excitability and action potential propagation (Bhave and Gereau, 2004). For example, the noxious heat transduction channel transient receptor potential vanilloid receptor 1 (TRPV1) can be sensitized by chronic TNF $\alpha$ treatment (Nicol et al., 1997), a possible mechanism for the development of heat hypersensitivity, but it is not obvious how TRPV1 modulation would mediate enhanced sensitivity to mechanical stimuli. Among other ion channels critical in the genesis of inflammatory and neuropathic pain are the TTX-resistant (TTX-R) sodium channels (Bhave and Gereau, 2004; Wood et al., 2004a,b). In the present study, we examined the modulation of TTX-R Na ${ }^{+}$channels in mouse DRG neurons by TNF $\alpha$. We show that acute application of TNF $\alpha$ to cultured mouse DRG neurons rapidly enhances TTX-R currents via a TNF receptor 1 (TNFR1)- and p38-dependent pathway. These studies provide the first evidence of rapid receptor-mediated modulation of nociceptor excitability by $\mathrm{TNF} \alpha$ and may provide an explanation for the rapid sensitization to mechanical stimuli induced by TNF $\alpha$.

\section{Materials and Methods}

Animals. Adult male mice, 6-8 weeks old, of the following strains, ICR (Taconic Farms, Germantown, NY), TRPV1 ${ }^{-/-}$, TNFp55rKO $\left(\right.$ TNFR $\left.^{-1-}\right)$, TNFp75rKO $\left(\right.$ TNFR2 $\left.^{-1-}\right)$, and their appropriate wildtype (WT) control strain (C57BL/6J) were purchased from The Jackson Laboratory (Bar Harbor, ME). All studies were performed under the guidelines of the National Institutes of Health and The International Association for the study of Pain and were approved by the Animal Care and Use Committee of Washington University School of Medicine.

Behavioral analysis. Mice were allowed to acclimate for $1 \mathrm{~d}$ before baseline testing. Mechanical sensitivity was assessed using von Frey hairs (North Coast Medical, San Jose, CA). Mice were placed on elevated wire mesh and allowed to acclimate to the testing environment for $2 \mathrm{~h}$ before testing. The plantar surface of the hindpaw was stimulated with a series of von Frey hairs. Each filament was applied five times, and threshold was determined as the lowest force that induced hindpaw withdrawal on at least three of five trials. Baseline values were defined as the mean of three measurements before injection. To test the effect of TNF $\alpha$ on the basal mechanical sensitivity, $1 \mathrm{ng}$ of TNF $\alpha$ (in $10 \mu \mathrm{l}$ ) was injected into the hindpaw plantar surface, and the paw-withdrawal thresholds of the ipsilateral hindpaw were measured at 30,45, 60, and 90 min after injection. For the inhibitor experiments, vehicle $(0.12 \%$ DMSO, $10 \mu \mathrm{l})$ or SB202190 [4-(4-fluorophenyl)-2-(4-hydroxyphenyl)-5-(4-pyridyl) $1 \mathrm{H}$ imidazole] $(12 \mu \mathrm{M}$ in $10 \mu \mathrm{l})$ was injected in the paw 20 min before the injection of TNF $\alpha$.

Thermal sensitivity was measured using radiant heat applied to the plantar surface of the hindpaw (IITC Life Sciences, Woodland Hills, CA). Paw-withdrawal latency was measured. The heat stimulus was terminated with a withdrawal response or cutoff at $20 \mathrm{~s}$ to avoid tissue damage. Before injections, three withdrawal latencies were recorded and averaged as the baseline for each animal. In TRPV1 ${ }^{-/-}$mice, the average baseline withdrawal latency was $14.31 \pm 2.17 \mathrm{~s}$. This was significantly different from wild-type littermates in which the baseline withdrawal latency was $6.81 \pm 0.97 \mathrm{~s}(p<0.01$, ANOVA). TNF $\alpha(1 \mathrm{ng}$ in $10 \mu \mathrm{l})$ was injected intradermally in the planter surface of the hindpaw, and withdrawal latencies were measured at 30, 45, 60, and 90 min after injection.

Preparation of DRG neuronal cultures. DRG neuronal cultures were prepared using procedures similar to those described in our previous publications (Hu et al., 2002; Yang and Gereau, 2004). DRGs were re-

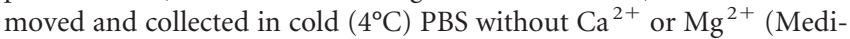
atech, Herndon, VA). Ganglia were incubated in $15 \mathrm{U} / \mathrm{ml}$ papain in HBSS (Mediatech) for $18 \mathrm{~min}$ at $37^{\circ} \mathrm{C}$. After this initial enzyme treatment, the ganglia were rinsed three times in HBSS and then incubated for $18 \mathrm{~min}$ with $1.5 \mathrm{mg} / \mathrm{ml}$ collagenase (Sigma, St. Louis, MO) in $\mathrm{HBSS}$ at $37^{\circ} \mathrm{C}$. After washing three times with HBSS, ganglia were gently triturated with a flame-polished Pasteur pipette. The tissue fragments were centrifuged at $1000 \mathrm{rpm}$ for $5 \mathrm{~min}$, and the pellet was resuspended in neurobasal culture media (Invitrogen, Grand island, NY) with 5\% FBS, 1\% B27, 100 $\mathrm{U} / \mathrm{ml}$ penicillin/streptomycin, and $2 \mathrm{~mm}$ glutamax. Cells were plated onto poly-D-lysine-coated $12 \mathrm{~mm}$ glass coverslips and maintained at $37^{\circ} \mathrm{C}$ in a $95 \%$ air $-5 \% \mathrm{CO}_{2}$ incubator overnight. Electrophysiological recordings were performed within $24 \mathrm{~h}$ of cell isolation.

Electrophysiological recording. Standard whole-cell patch-clamp recordings from cultured DRG neurons were performed at room temperature $\left(\sim 22^{\circ} \mathrm{C}\right)$ using an Axopatch $200 \mathrm{~B}$ amplifier. The pipettes were prepared on a Flaming-Brown horizontal puller (P-87; Sutter Instruments, Novato, CA) and fire polished. The resistance of the pipettes was 1-3 M $\Omega$. In whole-cell voltage-clamp mode, the pipette capacitance current was cancelled using the amplifier circuitry, and series resistance was compensated by $70-80 \%$. Currents were acquired using Clampex 8.2 software, filtered at $5 \mathrm{kHz}$, and digitized at a sampling rate of $20 \mathrm{kHz}$ via a Digidata 1322 series interface (Axon Instruments, Union City, CA). To determine the voltage dependence of activation, channels were fully inactivated by holding at $-100 \mathrm{mV}$ for $500 \mathrm{~ms}$ and then stepped to various test potentials from -60 to $25 \mathrm{mV}$ in $+5 \mathrm{mV}$ increments. The peak current amplitudes observed at the different test potentials were converted to macroscopic conductance using the equation $G=I /\left(V-V_{\mathrm{m}}\right)$, where $V$ is the calculated reversal potential. To determine the voltage dependence of inactivation, a two-pulse protocol was used. Conditioning prepulses ranging from -100 to $+20 \mathrm{mV}$ were applied at $5 \mathrm{~s}$ intervals in $+5 \mathrm{mV}$ increments for $1000 \mathrm{~ms}$, followed by test voltage $0 \mathrm{mV}$ for 100 $\mathrm{ms}$. The values for voltage of half-maximal activation or inactivation $\left(V_{1 / 2}\right)$ and slope factor $k$ were estimated by fitting the activation and steady-state inactivation curves with the Boltzmann equation $G=$ $G_{\max } /\left(1+\exp \left[\left(V_{1 / 2}-V_{\mathrm{m}}\right) / k\right]\right)$, where $V_{1 / 2}$ is the potential at which activation is half-maximal, $V_{\mathrm{m}}$ is the membrane potential, and $k$ is the slope factor.

For voltage-clamp experiments, the pipette solution contained the following (in mM): $120 \mathrm{KCl}, 20 \mathrm{HEPES}, 2.25 \mathrm{CaCl}_{2}, 5 \mathrm{EGTA}, 5 \mathrm{ATP}$, and 0.4 GTP. The $\mathrm{pH}$ of the solutions was adjusted to 7.2 with $\mathrm{KOH}$. To measure A-type transient potassium currents $\left(I_{\mathrm{A}}\right)$, cells were bathed in Tyrode's solution containing the following (in $\mathrm{mM}$ ): $140 \mathrm{NaCl}, 4 \mathrm{KCl}, 2$ $\mathrm{MgCl}_{2}, 2 \mathrm{CaCl}_{2}, 5$ glucose, and 5 HEPES, pH 7.4 (with $\mathrm{NaOH}$ ). To record $\mathrm{Na}^{+}$currents, the solution was switched to an external solution that suppressed $\mathrm{K}^{+}$and $\mathrm{Ca}^{2+}$ currents. This solution contained the following (in $\mathrm{mm}$ ): $40 \mathrm{NaCl}, 90$ tetraethylammonium (TEA)-Cl, 10 4-aminopyridine (4-AP), $10 \mathrm{HEPES}, 2 \mathrm{BaCl}_{2}, 0.1 \mathrm{CaCl}_{2}, 0.4 \mathrm{CdCl}_{2}$, and 10 glucose. The $\mathrm{pH}$ was adjusted to 7.4 with HEPES.

All patch-clamp analysis of $\mathrm{Na}^{+}$currents performed in this study was restricted to small-diameter DRG neurons with TTX-resistant sodium currents. These cells were identified in our studies by the presence of an $I_{\mathrm{A}}$-like current of $>200 \mathrm{pA}$ evoked during repolarization to $-50 \mathrm{mV}$ after a hyperpolarization to $-110 \mathrm{mV}$. We found that $100 \%$ of $I_{\mathrm{A}}$ expressing neurons expressed TTX-resistant sodium currents.

Immunohistochemistry. Cultured DRG neurons were washed with $\mathrm{Ca}^{2+}$-free PBS and treated with drugs diluted in the external solution used in $\mathrm{Na}^{+}$current recording experiments. Cells were fixed with $4 \%$ paraformaldehyde in $0.1 \mathrm{M}$ phosphate buffer for $30 \mathrm{~min}$ and blocked with $3 \%$ goat serum in $0.2 \%$ Triton X-100/PBS for $1 \mathrm{~h}$ at room temperature. The cells were then incubated with anti-phospho-p38 (p-p38) primary antibody (rabbit, 1:400; Cell Signaling Technology, Beverly, MA) over two nights at $4{ }^{\circ} \mathrm{C}$, followed by biotinylated secondary antibody (goat anti-rabbit, 1:100, Vector Laboratories, Burlingame, CA) for $1.5 \mathrm{~h}$ at room temperature and then extrAvidin peroxidase (1:100; Sigma) for $1 \mathrm{~h}$ at room temperature. DAB (Vector Laboratories) was used for detection. The level of $\mathrm{p} 38$ phosphorylation in the cultures was quantified by both counting p-p38-immunoreactive neurons and by measuring the intensity of staining using a computerized image analysis system (SimplePCI; Compix, Lake Oswego, OR). For each condition, 100 cells were selected at random, and the staining intensity (in arbitrary units, ranging from 0 to 255) was measured from each cell while subtracting background. For a given experiment, identical exposure times and illumination intensities were used for all treatment conditions, and the experimenter was blind to treatment during the random selection and measurement of staining intensities.

Drug application. Recombinant murine TNF $\alpha$ was obtained from R \& 

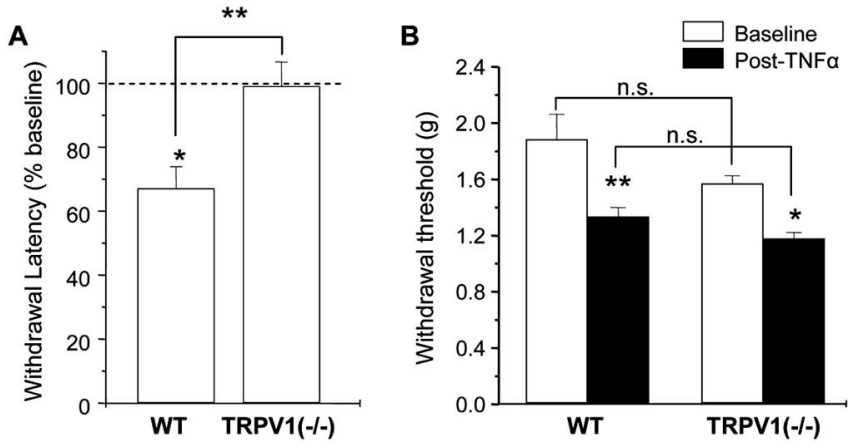

Figure 1. Loss of TNF $\alpha$-induced thermal hyperalgesia, but not mechanical hypersensitivity, in TRPV1 ${ }^{-1-}$ mice. Thermal withdrawal latencies (expressed as percentage of preinjection baseline values) ( $\boldsymbol{A}$ ) and mechanical withdrawal thresholds (in grams) ( $\boldsymbol{B}$ ) before (baseline) and after intraplantar injection of TNF $\alpha(1 \mathrm{ng} / 10 \mu \mathrm{l})$ in TRPV $1^{-1-}$ mice and WT littermates. The experimenter was blind to the genotype of the animals. Three measurements were taken from each animal over a period of $30-90$ min after TNF $\alpha$ injection, and the average was taken as the postinjection withdrawal threshold. Asterisks above the bars indicate the results of comparisons for each condition to the preinjection baseline (paired $t$ test for $A$; ANOVA for $B$ ). Asterisks above the brackets indicate results of comparisons between the genotypes (unpaired $t$ test in $A$; ANOVA with post hoc Tukey's test for $\boldsymbol{B}$ ). ${ }^{*} p<0.05 ;{ }^{* *} p<0.01 . n=6-9$ animals per condition. n.s., Not significant.

D Systems (Minneapolis, MN) and prepared as concentrated stock solutions at $50 \mu \mathrm{g} / \mathrm{ml}$ in $0.1 \%$ BSA. 4-AP was purchased from Sigma. SB202190 and its inactive analog SB202474 [4-ethyl-2( $p$ methoxyphenyl)-5-(4'-pyridyl)-1H-imidazole] were purchased from Calbiochem (La Jolla, CA) and dissolved in DMSO (final concentration, $0.12 \%)$.

Statistical analysis. All data are expressed as mean \pm SEM. Treatment effects were statistically analyzed by one-way ANOVA, followed by post hoc analysis using the Bonferroni's correction, Tukey's test, or Dunnett's test for multiple comparisons as indicated using Statistica Software (Statsoft, Tulsa, OK). Student's $t$ test was used when comparisons were restricted to two experimental groups. Error probabilities of $p<0.05$ were considered statistically significant.

\section{Results}

TNF $\alpha$-induced thermal and mechanical hypersensitivity: the role of TRPV 1

As mentioned above, application of TNF can sensitize the noxious heat transduction channel, TRPV1(Nicol et al., 1997). It is clear that this modulation of TRPV1 could underlie the induction of heat hypersensitivity by $\operatorname{TNF} \alpha$, but it is less obvious how TRPV1 modulation would mediate the enhanced sensitivity to mechanical stimuli induced by TNF $\alpha$. To test the hypothesis that TRPV1 is required only for TNF $\alpha$-induced thermal hypersensitivity, we examined the induction of thermal and mechanical hypersensitivity by intraplantar injection of TNF $\alpha$ in TRPV1 $1^{-1-}$ mice and wild-type littermates. Consistent with previous reports, we found that intraplantar injection of TNF $\alpha$ induced both thermal and mechanical hypersensitivity in wild-type mice (Fig. 1). However, thermal hypersensitivity was not observed in TRPV1 $1^{-/-}$mice, whereas mechanical hypersensitivity in TRPV1 $1^{-/-}$mice was not significantly different from that observed in WT littermates. These data support the hypothesis that TNF $\alpha$-induced thermal hyperalgesia requires the expression of TRPV1, whereas TNF $\alpha$-induced mechanical hypersensitivity occurs via a TRPV1-independent mechanism.

\section{Characterization of TTX-resistant $\mathrm{Na}^{+}$currents in mouse DRG neurons}

Previous studies suggest that TTX- $\mathrm{R} \mathrm{Na}^{+}$currents and TNF receptors are colocalized with TRPV1 and other nociceptive mark- ers in a subpopulation of DRG neurons (Cardenas et al., 1995, 1997; Li et al., 2004). To minimize variability in our recordings, we chose to record from an electrophysiologically identified subclass of DRG neurons that is likely to include neurons expressing both TTX- $\mathrm{R} \mathrm{Na}^{+}$channels and TNF receptors. To do this, we used electrophysiological signatures to classify small-diameter DRG neurons, as described in Materials and Methods. Smalldiameter DRG neurons with an $I_{\mathrm{A}}$ of $>200 \mathrm{pA}$ were selected for study. $I_{\mathrm{A}}$ was measured using the protocol as shown in Figure $2 \mathrm{~A}$. These were small-diameter DRG neurons, with an average diameter of $25 \pm 2.5 \mu \mathrm{m}$. The average peak current of $I_{\mathrm{A}}$ in these cells was $435 \pm 26$ pA. Following this classification, $\mathrm{Na}^{+}$currents were measured using an external solution containing TEA and 4 -AP to block $\mathrm{K}^{+}$currents and $\mathrm{CdCl}_{2}$ to block $\mathrm{Ca}^{2+}$ currents. Figure $2 \mathrm{~B}$ shows an example of original $\mathrm{Na}^{+}$current records obtained from an $I_{\mathrm{A}}$-expressing DRG neuron. To define whether currents were TTX resistant, we perfused the cells with $250 \mathrm{~nm}$ TTX for 3 min. There was no significant reduction in current amplitude in the presence of TTX. This is in agreement with previous studies showing that rat DRG neurons that express a prominent $I_{\mathrm{A}}$ also express only TTX-resistant $\mathrm{Na}^{+}$currents (Cardenas et al., 1999, 2001). The peak current value at multiple potentials was recorded to generate $I-V$ curves (Fig. $2 C$ ), and the voltage dependence of activation and steady-state inactivation were measured using protocols as shown in Figure $2 D$. The activation curve had an average $V_{1 / 2}$ of $-23.57 \mathrm{mV}$ and a slope factor of $6.95(n=15)$, whereas the $V_{1 / 2}$ for inactivation averaged $-39.21 \mathrm{mV}$ with a slope factor of $10.16(n=12)$.

\section{TNF $\alpha$ enhances TTX-R Na ${ }^{+}$currents}

Previous studies have reported that TNF $\alpha$ can evoke action potentials and increase discharge rates when applied locally to nociceptive neurons (Sorkin et al., 1997; Junger and Sorkin, 2000; Sorkin and Doom, 2000; Liu et al., 2002). The mechanisms underlying this alteration in firing are not known, and we hypothesized that this effect of TNF $\alpha$ might be mediated in part by modulation of TTX- $\mathrm{R} \mathrm{Na}^{+}$channels. As illustrated from the representative recording in Figure $3 A-C$, bath application of mouse recombinant TNF $\alpha(100 \mathrm{ng} / \mathrm{ml})$ rapidly enhanced peak TTX-R $\mathrm{Na}^{+}$currents. The enhancement of TTX-R currents by TNF $\alpha$ was typically observed within $\sim 1$ min of the onset of TNF $\alpha$ application and reached its peak effect within 3-5 min. This effect was concentration dependent, with significant potentiation of TTX-R currents seen at 20,50, and $100 \mathrm{ng} / \mathrm{ml} \mathrm{TNF} \alpha$, as shown in Figure $3 D$. The largest increase in currents was observed at 100 $\mathrm{ng} / \mathrm{ml} \mathrm{TNF} \alpha$, in which we observed a $37.7 \%$ increase in peak currents compared with the pre-TNF $\alpha$ current amplitude.

We also determined the effects of TNF $\alpha$ on biophysical properties of TTX-R currents, including conductance, the voltage dependence, and slope factor in both activation and steady-state inactivation from each individual cell. The results of this analysis are shown in Table 1. Application of TNF $\alpha$ resulted in a significant increase in total TTX-R conductance from $121.23 \pm 21.43$ to $172.20 \pm 25.30 \mathrm{pS}(n=8)$. However, TNF $\alpha$ had no effect on the gating properties as assessed by comparing $V_{1 / 2}$ and $k$ in the activation or steady-state inactivation curves.

\section{p38 mitogen-activated protein kinase modulates TTX-R Na ${ }^{+}$} currents and mediates sensitization of TTX-R by TNF $\alpha$ It has been reported that TNF receptors can signal through activation of the p38 mitogen-activated protein kinase (MAPK) cascade in DRG neurons as well as many other cell types (Pollock et al., 2002; Wu, 2004). Furthermore, p38 inhibitors can block 
A
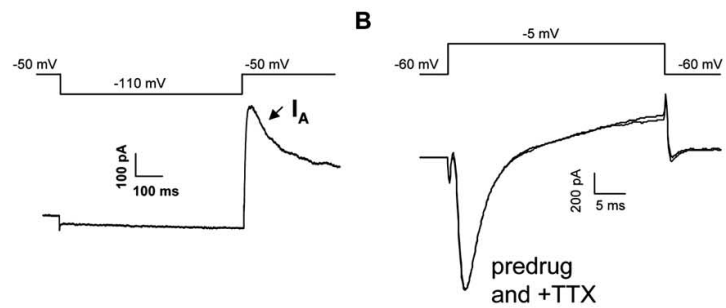

C
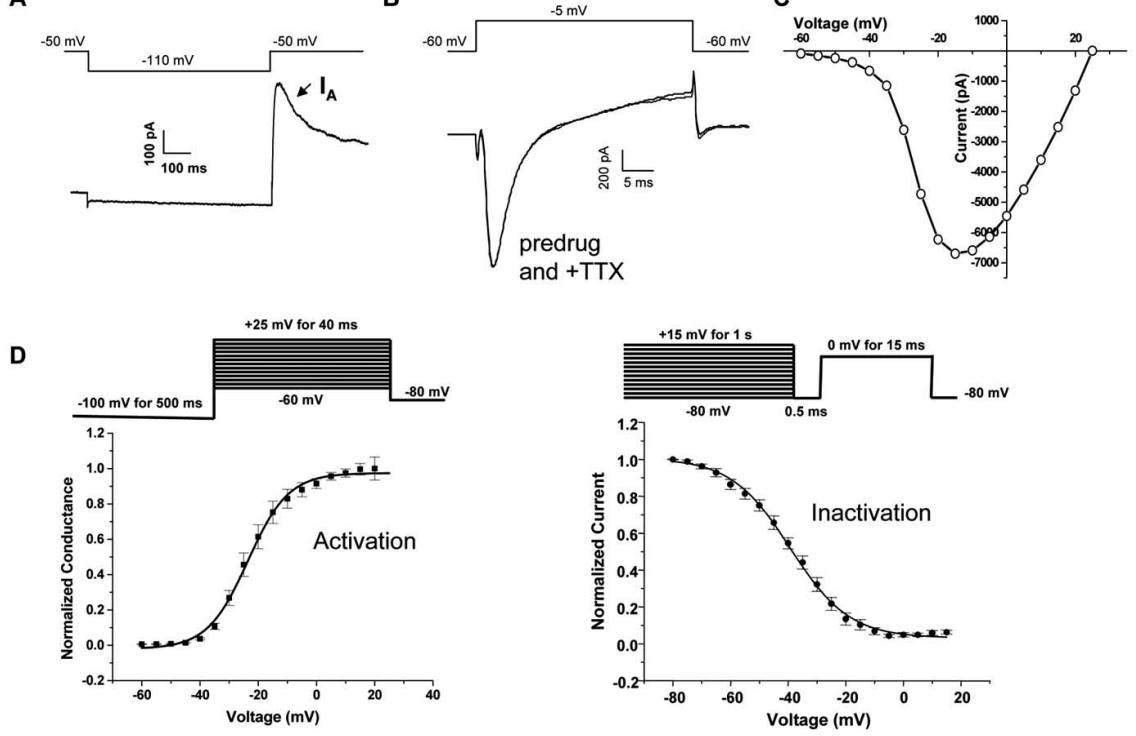

Figure 2. Characteristics of TTX-resistant sodium currents in mouse DRG neurons. $A$, Representative current response showing a prominent A-type $K^{+}$current used to identify TTX-R expressing DRG neurons. $I_{A}$ was evoked using the voltage protocol shown above the current trace. $\boldsymbol{B}$, Representative inward $\mathrm{Na}^{+}$current recorded before and after application of TTX ( $250 \mathrm{~nm}$ for $3 \mathrm{~min}$ ). Note that traces of predrug and with TTX are superimposed. TTX had no effect on $\mathrm{Na}^{+}$currents in $I_{A}$-positive DRG neurons. $\boldsymbol{C}$, Representative current-voltage relationship for peak TTX-R currents. $\boldsymbol{D}$, Steady-state inactivation $(n=12)$ and activation $(n=15)$ curves for TTX-R currents obtained using the voltage protocols shown above the graphs.

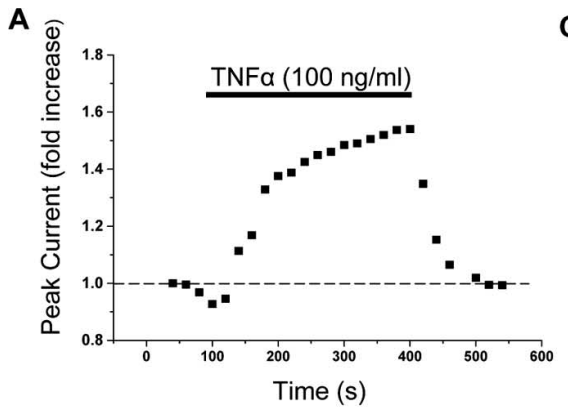

C

B

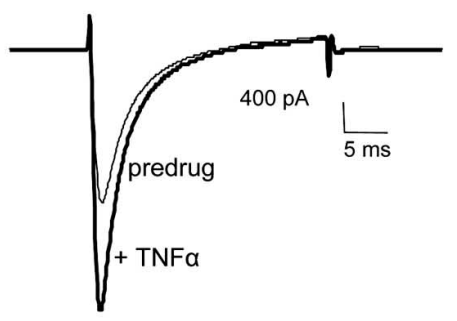

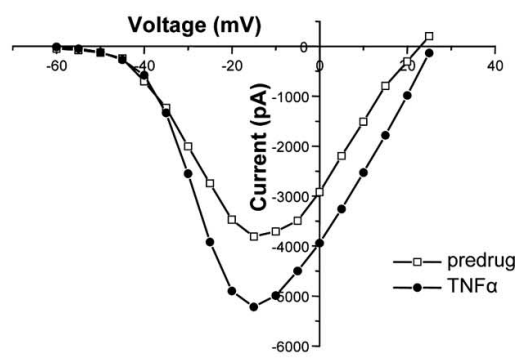

D

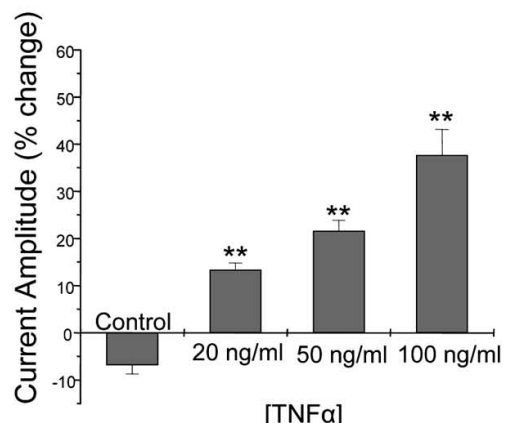

$[\mathrm{TNF \alpha}]$

Figure 3. TNF $\alpha$ enhances TTX-R $\mathrm{Na}^{+}$currents. $A$, Plot of peak $\mathrm{Na}^{+}$current amplitude versus time in a representative cell showing the effect of application of TNF $\alpha$ (recombinant murine TNF $\alpha, 100 \mathrm{ng} / \mathrm{ml}$ ). Peak current was measured every 20 s. The duration of TNF $\alpha$ perfusion is indicated by the bar above the trace. Representative traces $(\boldsymbol{B})$ and $I-V$ plots $(\boldsymbol{C})$ showing inward $\mathrm{Na}^{+}$currents recorded before and during application of TNF $\alpha(100 \mathrm{ng} / \mathrm{ml})$. D, Dose-response relationship for TNF $\alpha$-induced enhancement of TTX-R currents. Values represent the mean \pm SEM percentage change in amplitude of peak current induced by vehicle (BSA) or various doses of TNF $\alpha$ $(n=7)$. The decreased current in the control represents time-dependent rundown of TTX-R currents over the duration of the recording. ${ }^{*} p \leq 0.05 ;{ }^{* *} p \leq 0.01$ compared with the control condition, ANOVA with post hoc Dunnett's test.

TNF-induced pain sensitization in vivo (Schafers et al., 2003b). These data suggest the possibility that TNF $\alpha$ might modulate TTX-R Na ${ }^{+}$currents via activation of p38 MAPK. We therefore investigated the role of p38 MAPK in the TNF $\alpha$ - induced enhancement in TTX- $\mathrm{R} \mathrm{Na}^{+}$currents in cultured mouse DRG neurons. First, we exposed DRG neurons to the p38 inhibitor SB202190 alone for at least 3 min. We found that SB202190 induced a significant decrease in basal TTX-R Na ${ }^{+}$ currents in these cells (Fig. 4). The average peak current was reduced by $19.03 \pm$ $2.84 \%(n=19)$ in the presence of SB202190 $(10 \mu \mathrm{M})$, whereas in vehicle (0.1\% DMSO)-treated cells under the same recording conditions, currents were reduced by an average of only $6.38 \pm$ $1.84 \%(n=13)$. The decrease under the control conditions represents the typical time-dependent rundown of TTX-R currents observed over a 5 min recording period under our conditions (Figs. 3D, $4 D$ ) (see Fig. 7C). SB202190 had no effect on $V_{1 / 2}$ or the slope factor but significantly decreased maximal conductance (Table $1)$. The $G_{\max }$ was $118.92 \pm 11.77 \mathrm{pS}$ under control conditions and was 88.11 \pm 11.34 pS $(n=8)$ after SB202190 application. In contrast to the effects of the p38 inhibitor SB202190, TTX-R currents were not significantly reduced relative to control in the presence of SB202474 $(10 \mu \mathrm{M})$, an inactive structural analog of SB202190 that does not inhibit p38 (Lee et al., 1994) (Fig. 4D).

The effects of SB202190 were precisely the opposite of what was observed with TNF $\alpha$ application, suggesting that there might be basal p38 activation in these cells and further that p38 might mediate the potentiation of TTX-R currents induced by TNF $\alpha$. To test this hypothesis, we next investigated whether the enhancement of TTX-R currents by TNF could be blocked by inhibition of p38. Cells were treated with SB202190 $(10 \mu \mathrm{M})$ before and during application of TNF $\alpha(100 \mathrm{ng} / \mathrm{ml})$. Under these conditions, TNF had no significant effect on TTX-R currents compared with vehicletreated cells (Fig. 5). Pretreatment with SB202190 decreased peak currents and abolished the TNF-induced enhancement of TTX-R.

It should be noted that, in some of our recordings, there was a residual unblocked outward current (Figs. 2B, $4 B$ ). It is conceivable that, in cells in which there is significant unblocked outward current, some of the effects of TNF $\alpha$ or the p38 inhibitor on the amplitude of the inward current may be impacted by effects on this outward current. However, we did not see significant effects on this outward current, and we have observed modulation of TTX-R sodium currents by TNF $\alpha$ and the p38 inhibitor in cells with no unblocked outward current. Thus, modulation of the unblocked outward current is not the primary mechanism for this modulation. 
Table 1. Effects of TNF $\alpha(100 \mathrm{ng} / \mathrm{ml})$ and SB202190 (10 $\mu \mathrm{M})$ on properties of TTX-R Na ${ }^{+}$currents in mouse DRG neurons

\begin{tabular}{|c|c|c|c|c|c|c|c|c|c|c|c|c|}
\hline & \multicolumn{4}{|l|}{$V_{1 / 2}$} & \multicolumn{4}{|l|}{ Slope factor } & \multicolumn{4}{|l|}{$G_{\max }$} \\
\hline & Pre-TNF $\alpha$ & Post-TNF $\alpha$ & Pre-SB & Post-SB & Pre-TNF $\alpha$ & Post-TNF $\alpha$ & Pre-SB & Post-SB & Pre-TNF $\alpha$ & Post-TNF $\alpha$ & Pre-SB & Post-SB \\
\hline Activation & $-24.19 \pm 3.61$ & $-22.94 \pm 6.2$ & $-18.86 \pm 2.8$ & $-17.64 \pm 3.3$ & $4.01 \pm 1.01$ & $5.42 \pm 1.03$ & $6.76 \pm 0.47$ & $5.42 \pm 0.52$ & $121.59 \pm 12.99$ & $172.21 \pm 25.3^{*}$ & $118.92 \pm 11.77$ & $88.11 \pm 11.34^{*}$ \\
\hline Inactivation & $-34.13 \pm 4.17$ & $-43.88 \pm 6.24$ & $-40.64 \pm 6.24$ & $-39.41 \pm 2.15$ & $11.52 \pm 1.67$ & $10.65 \pm 0.99$ & $7.36 \pm 0.76$ & $8.04 \pm 3.59$ & & & & \\
\hline
\end{tabular}

${ }^{*} p<0.05$ indicates significant differences by paired $t$ test. SB, SB202190.

TNF activates p38 MAPK in mouse DRG neurons in vitro

The electrophysiological data described above strongly suggest that p38 MAPK mediates the modulation of TTX-R Na ${ }^{+}$currents by TNF $\alpha$ and suggest that TNF $\alpha$ activates p38 in mouse DRG neurons. To test this more directly, we used immunohistochemistry to determine whether TNF caused increases in active (phosphorylated) p38 in mouse DRG neurons under conditions similar to those used in our electrophysiological recordings. Cultured DRG neurons were treated with $\mathrm{TNF} \alpha(100 \mathrm{ng} / \mathrm{ml})$ or anisomycin (200 nM, as a positive control) for $20 \mathrm{~min}$. The cells were then fixed and processed for immunohistochemistry using a phosphospecific p38 antibody. As illustrated in Figure $6 A$, there were few neurons labeled for $\mathrm{p}-\mathrm{p} 38$ in control DRG cultures, consistent with previous reports (Pollock et al., 2002; Schafers et al., $2003 \mathrm{~b}$ ). Application of TNF $\alpha$ clearly induced p38 activation, both in terms of staining intensity and in the number of positive cells, to an extent similar to that observed in response to the positive control (anisomycin). TNF $\alpha$ increased the percentage of p-p38immunoreactive neurons to $14.9 \%$ compared with $5.4 \%$ in control cultures; a similar enhancement was observed with anisomycin. The staining intensity (in arbitrary units ranging from 0 to 255) of p-p38 immunoreactivity was also increased to $62.04 \pm 2.35$ in $\mathrm{TNF} \alpha$ treatment from $49.31 \pm 1.51$ in control conditions, again similar to what was observed with anisomycin.

\section{The role of TNFR1 in the modulation of} TTX-R currents by TNF $\alpha$

Recent evidence has indicated that TNFR1 (p55) and TNFR2 (p75) are expressed in rat DRG neurons (Shubayev and Myers, 2001; Pollock et al., 2002), although the presence of TNFR2 in these cells is controversial (Li et al., 2004; Inglis et al., 2005). To test whether the TNF $\alpha$-induced enhancement of TTX-R currents occurs via activation of TNFR1, TNFR2, or both receptors, we compared the effects of TNF $\alpha$ on TTX-R Na ${ }^{+}$currents in DRG neurons prepared from wild type with those prepared from TNFR1 or TNFR2 knock-out mice. The TNFR1 ${ }^{-1-}$ and TNFR2 ${ }^{-1-}$ mice were generated in the C57BL/6J strain (Pfeffer et al., 1993; Erickson et al., 1994), so C57BL/6J mice were used as wild-type controls for this experiment. We detected no major differences in
A

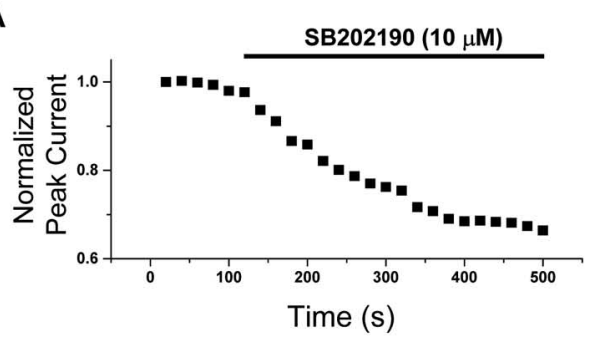

C

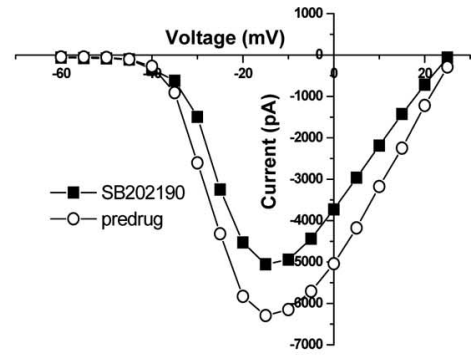

B

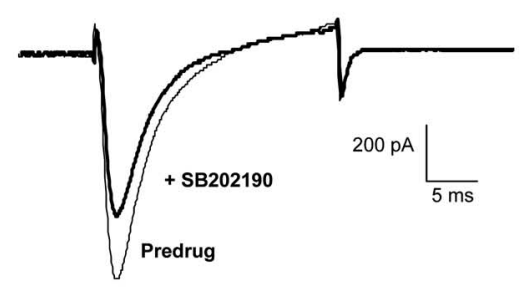

D

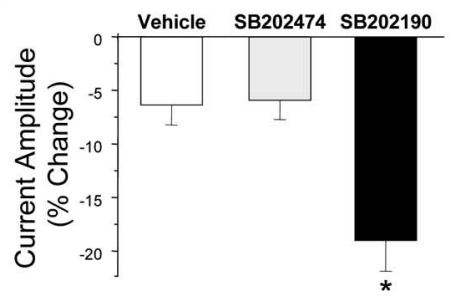

Figure 4. $\quad$ p38 MAPK modulates TTX-R Na ${ }^{+}$currents. $A$, Representative time course showing inhibition of basal TTX-R $\mathrm{Na}^{+}$ currents after bath application of the p38 MAPK inhibitor SB202190 (10 $\mu \mathrm{M})$. Current traces $(\boldsymbol{B})$ and $I-V$ curves $(\boldsymbol{C})$ showing the inhibition of TTX-R currents under control conditions (vehicle of 0.1\% DMSO) and after SB202190 treatment. D, Grouped data showing the mean percentage change in peak current amplitude over time induced by SB202190 $(n=19)$ or its inactive control analog SB202474 $(10 \mu \mathrm{M})(n=8)$ compared with vehicle (DMSO; $n=13) .{ }^{*} p<0.05$ versus the vehicle control, ANOVA.

A

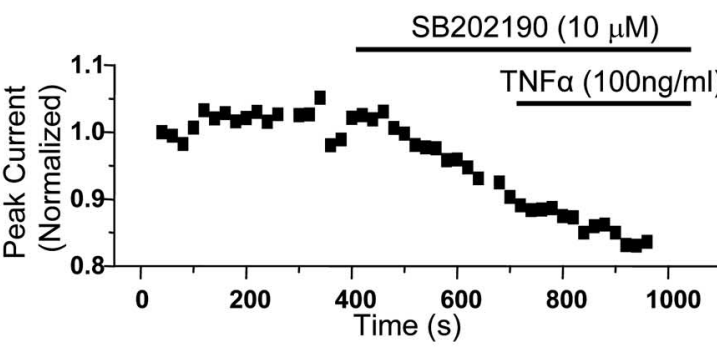

$\mathbf{B}$

C
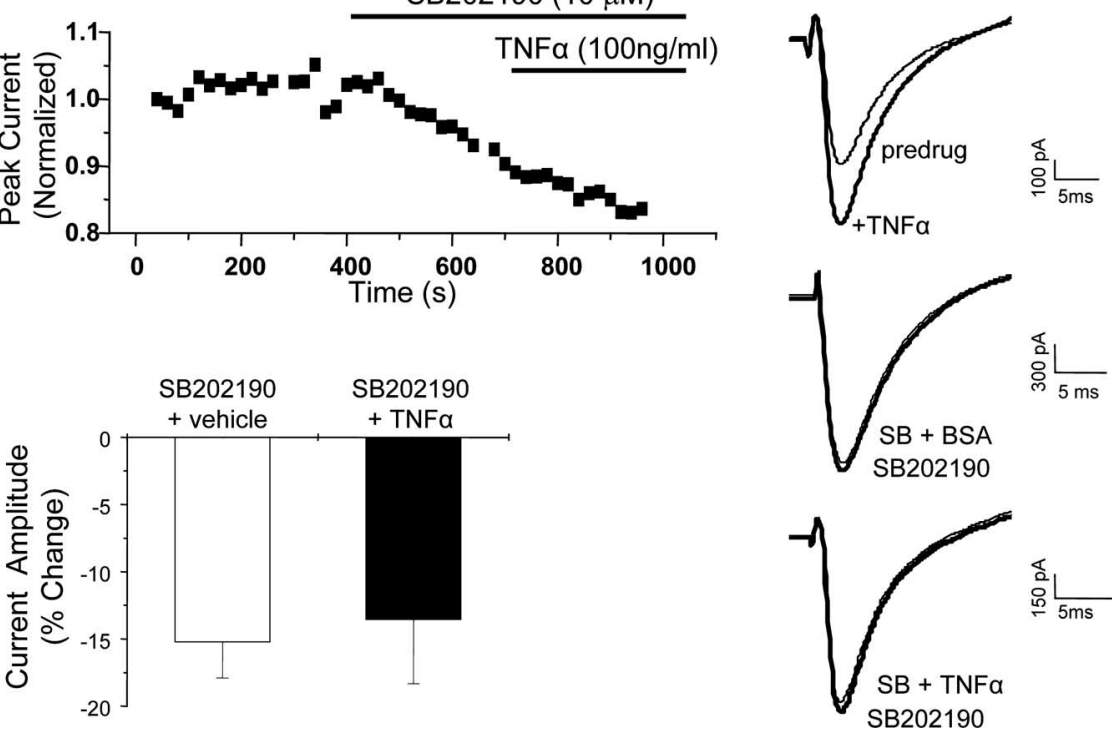

Figure 5. $\mathrm{p} 38 \mathrm{MAPK}$ is required for TNF $\alpha$ modulation of TTX-R Na ${ }^{+}$currents. $A$, Representative time course showing the change in peak current amplitude in response to application of TNF $\alpha$ in the presence of the p38 inhibitor SB202190. TNF $\alpha$ failed to produce enhancement when the cell was pretreated with SB202190 (10 $\mu \mathrm{M})$ for $3 \mathrm{~min}$. $\boldsymbol{B}$, Representative current traces (truncated for clarity) showing the effects of TNF $\alpha$ in the absence (top) and presence (bottom) of SB202190. BSA is the vehicle used for TNF $\alpha$, and BSA had no effect on TTX-R currents under control conditions (data not shown) or in the presence of SB202190 (middle). C, Grouped data showing the mean \pm SEM percentage change in peak current after application of SB202190 plus BSA and SB202190 plus TNF $\alpha$. The two groups are not significantly different. 
A

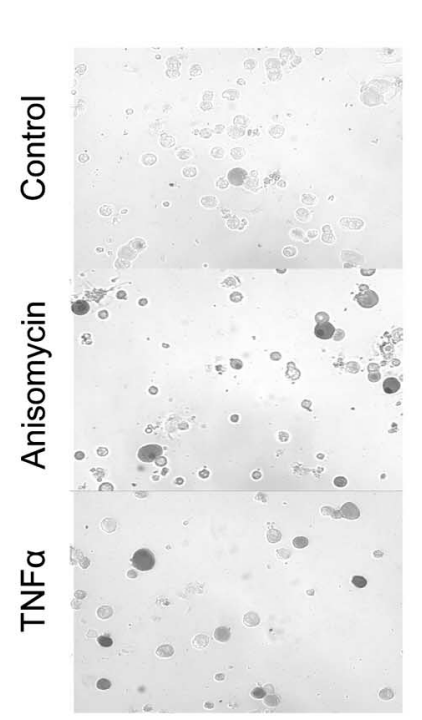

B

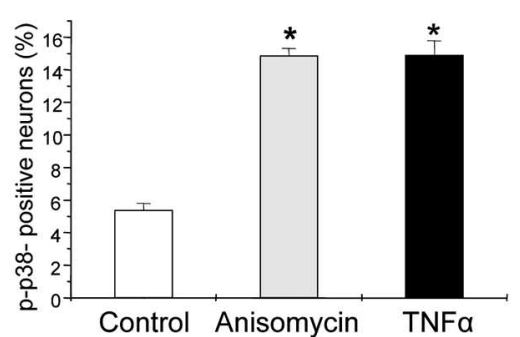

C

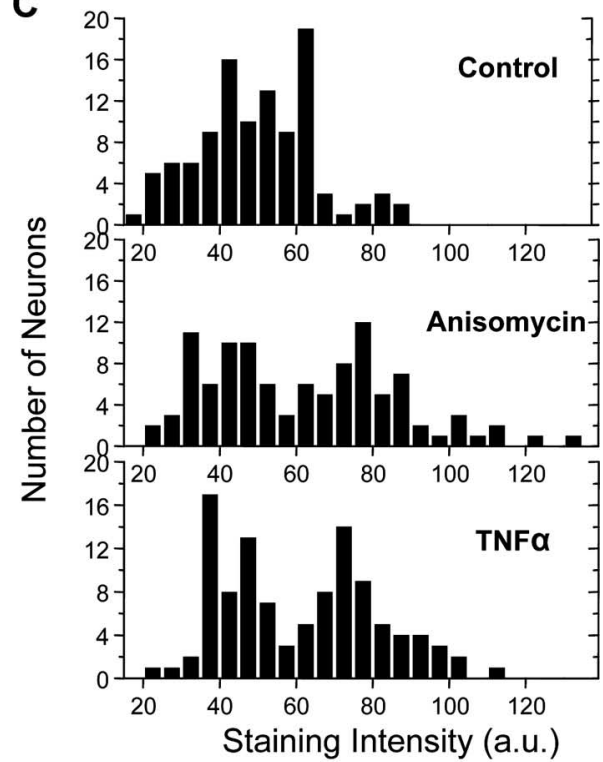

D

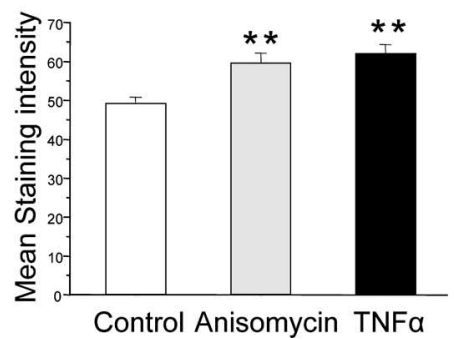

Figure 6. TNF $\alpha$ activates p38 MAPK in isolated mouse DRG neurons. Phospho-p38 immunohistochemical analysis of cultured DRG neurons exposed to TNF $\alpha(100 \mathrm{ng} / \mathrm{ml})$ and anisomycin ( $200 \mathrm{~nm}$, as a positive control) for $20 \mathrm{~min}$. $A$, Representative images showing increased phospho-p38 immunoreactivity visualized by DAB in response to both anisomycin and TNF $\alpha$ relative to parallel control cultures (original magnification, $200 \times$ ). $\boldsymbol{B}$, Average data from three separate experiments showing the increase in the percentage of phospho-p38-positive cells in response to anisomycin and TNF $\alpha .{ }^{*} p<0.05$ compared with control. One hundred randomly selected neurons were measured from each condition. C, Quantification of staining intensity of 100 individual neurons in each condition showing an increase in more densely labeled neurons after TNF $\alpha$ and anisomycin treatment. Staining intensity is represented as arbitrary units (a.u.) ranging from 0 to 255 based on the grayscale intensity level for each pixel. $\boldsymbol{D}$, Grouped data showing the mean \pm SEM staining intensity of DRG neurons under the three conditions. ${ }^{*} p<0.01$ compared with control.

A

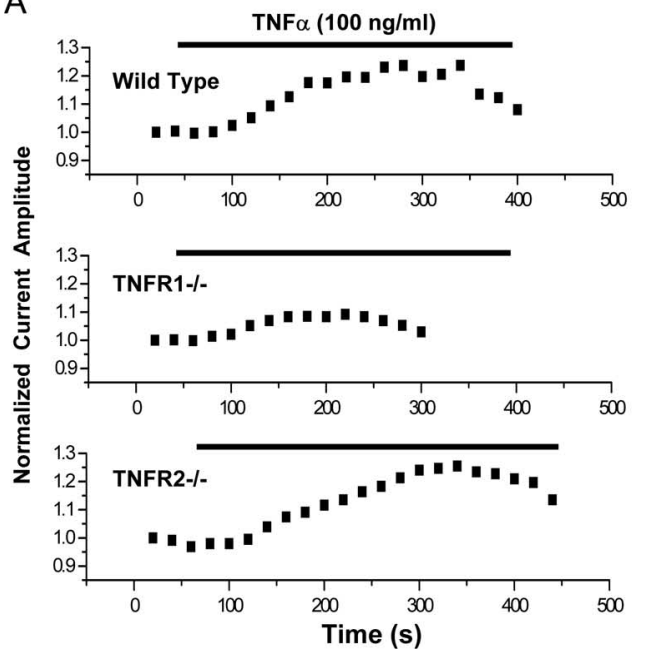

B

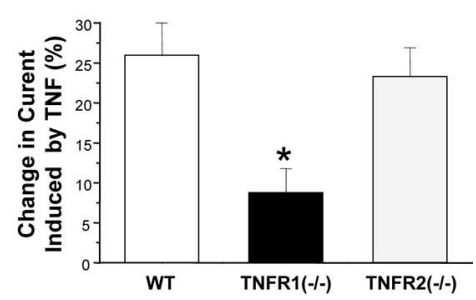

C

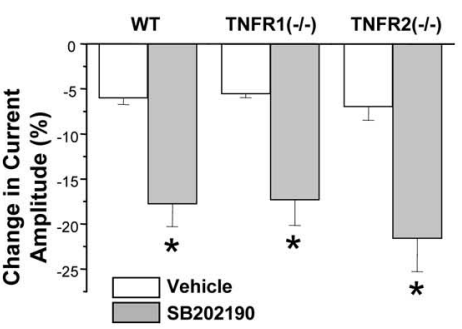

Figure 7. TNFR1 mediates the TNF $\alpha$-induced modulation of TTX-R Na ${ }^{+}$currents. $A$, Representative time courses of the peak TTX-R current showing the effect of bath application of TNF $\alpha$ in DRG neurons prepared from WT, TNFR ${ }^{-1-}$, or TNFR2 ${ }^{-/-}$mice. $B$, Mean \pm SEM percentage change of TTX-R peak currents induced by TNF $\alpha$ in TNFR1 $1^{-1-}$ and TNFR2 ${ }^{-/-}$DRG cells compared with wild type. C, Mean \pm SEM percentage change of TTX-R peak currents induced by the p38 inhibitor SB202190 (10 $\mu \mathrm{M})$ in TNFR $1^{-/-}$and TNFR2 ${ }^{-/-}$DRG cells compared with wild type.

DRG neurons in the C57BL/6J strain compared with the ICR mice used in the experiments above, including that there was no significant difference in the magnitude of potentiation of TTX-R by TNF $\alpha$ (potentiation in ICR mice by TNF was $37.68 \pm$ $5.49 \%$, and, in C57BL/6 mice, the potentiation averaged $26.14 \pm 4.0 \% ; p>0.1$, ANOVA). As shown in Figure 7, the TNF $\alpha$ $(100 \mathrm{ng} / \mathrm{ml})$-induced enhancement of TTX-R currents was significantly reduced in TNFR1 $1^{-1-}$ mice relative to WT controls, with a $66 \%$ decrease in the enhancement of TTX-R currents in TNFR $1^{-/-}$ mice. In contrast, the enhancement of TTX-R currents by TNF $\alpha$ was not significantly reduced in the TNFR2 $2^{-/-}$mice relative to WT controls. This suggests that TNF $\alpha$ sensitization of TTX- $\mathrm{R} \mathrm{Na}^{+}$channels is dependent on TNFR1 but not TNFR2.

The p38 inhibitor SB202190 induced a similar inhibition of basal TTX- $\mathrm{R} \mathrm{Na}^{+}$ currents in TNFR1 $1^{-/-}$, TNFR2 $^{-/-}$, and wild-type mice. This suggests that the basal p38 activity in mouse DRG neurons is not attributable to basal activity of TNFR1 or TNFR2. The inhibition by SB202190 was similar in neurons prepared from wild-type C57BL/6J and ICR mice.

\section{p38 activity is required for mechanical} hypersensitivity induced by TNF $\alpha$

Thus far, our results suggest that $\operatorname{TNF} \alpha$ promotes thermal hyperalgesia (but not mechanical hypersensitivity) via a TRPV1-dependent mechanism. Furthermore, our biochemical and electrophysiological studies show that TNF $\alpha$ can sensitize TTX-R sodium channels via activation of $\mathrm{p} 38$. If this sensitization of TTX-R sodium channels underlies mechanical hypersensitivity induced by TNF $\alpha$, then this hypersensitivity should be reduced by inhibition of the p38 pathway. To test this hypothesis, we performed behavioral studies in which male ICR mice were pretreated with the p38 inhibitor SB202190 $(12 \mu \mathrm{M}$ in $10 \mu \mathrm{l})$ or vehicle $(0.12 \%$ DMSO) 20 min before intraplantar injection of TNF $\alpha$ ( $1 \mathrm{ng}$ in $10 \mu \mathrm{l})$. Intraplantar injection of TNF $\alpha$ induced robust mechanical hypersensitivity in the vehiclepretreated mice. This hypersensitivity was significantly reduced when mice were pretreated with the p38 inhibitor SB202190, whereas treatment with vehicle or SB202190 alone did not produce any significant analgesia (Fig. 8). These data suggest that mechanical hypersensitivity induced by TNF $\alpha$ is dependent on the p38 pathway.

The present results show that TNF $\alpha$ in- 


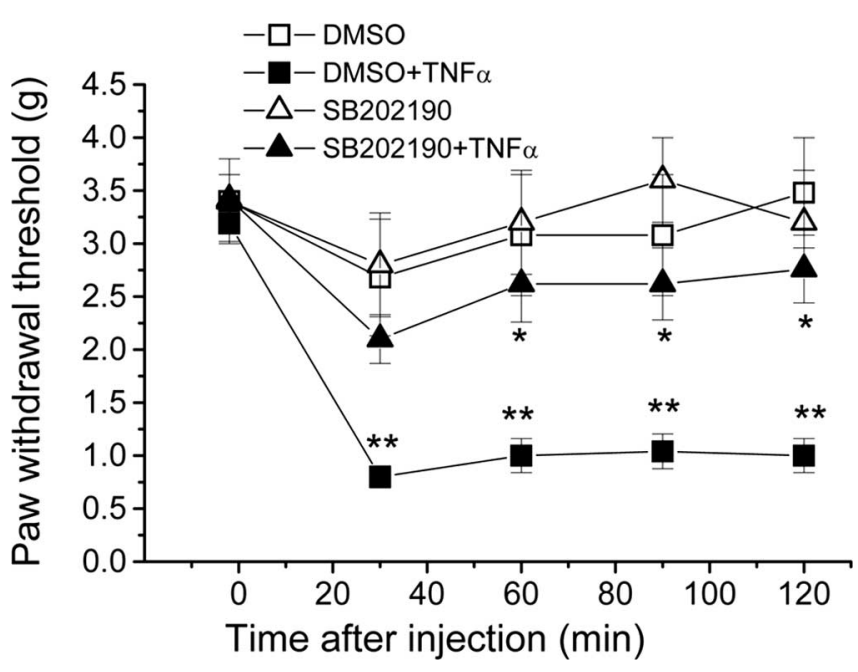

Figure 8. p38 activity is required for mechanical hypersensitivity induced by TNF $\alpha$. ICR mice were pretreated with the p38 inhibitor SB202190 (12 $\mu \mathrm{m}$ in $10 \mu \mathrm{l}$ ) or vehicle (0.1\% DMSO) alone or 20 min before intraplantar injection of TNF $\alpha$ (1 ng in $10 \mu l)$. The graph shows the mean \pm SEM mechanical withdrawal thresholds over time before and after injection of TNF $\alpha$. The experimenter was blind to the identity of the preinjection drug. ${ }^{*} p<0.05$ compared with DMSO plus TNF $\alpha$-treated mice. $n=6$ for each condition. ${ }^{* *} p<0.001$, ANOVA compared with DMSO-treated mice.

duces mechanical and thermal hypersensitivity in WT mice but only mechanical hypersensitivity in $T R P V 1^{-/-}$mice (Fig. 1). This complete deficit in TNF $\alpha$-induced thermal hyperalgesia in $T R P V 1^{-/-}$mice is curious given that TNF $\alpha$ still induces a robust sensitization of TTX-R Na ${ }^{+}$currents in DRG neurons prepared from TRPV1 ${ }^{-/-}$mice (TNF $\alpha$-induced potentiation of TTX-R is $26.12 \pm 4.0(n=7)$ in WT mice compared with $25.43 \pm 3.33(n=$ 7) in TRPV1 ${ }^{-1-}$ mice; data not shown). Together, these results collectively suggest that thermal hyperalgesia induced by peripherally applied TNF $\alpha$ is mediated via TRPV1 and not TTX-R sodium channels, whereas mechanical hypersensitivity induced by TNF $\alpha$ does not require TRPV1 and may involve modulation of TTX-R sodium channels.

\section{Discussion}

Peripheral administration of TNF $\alpha$ can induce rapid sensitization to both thermal and mechanical stimuli. Nicol et al. (1997) showed previously that TNF $\alpha$ can sensitize the noxious heatsensing protein TRPV1. Whether this effect is mediated by transcriptional or posttranslational mechanisms is not known, although it requires the increased production of prostaglandin E2. TRPV1 sensitization was induced by prolonged pretreatment with TNF $\alpha$ (>4 h) (Nicol et al., 1997). If TNF $\alpha$ can also rapidly sensitize TRPV1, then this could explain the ability of TNF $\alpha$ to cause rapid sensitization to thermal stimuli. This hypothesis is supported by our findings that TNF $\alpha$ induces thermal hyperalgesia in wild-type mice but not in their TRPV1 $1^{-/-}$littermates. TRPV1 modulation is not involved in peripheral mechanical sensitization induced by $\mathrm{TNF} \alpha$, however, because we found no reduction in tactile hypersensitivity in $T R P V 1^{-/-}$mice compared with WT littermates.

$\mathrm{TNF} \alpha$ has been shown to regulate a variety of ion channels in the nervous system. For example, TNF $\alpha$ decreases outward $\mathrm{K}^{+}$ currents in retinal ganglion neurons (Diem et al., 2001) and increases L-type $\mathrm{Ca}^{2+}$ currents in hippocampal (Furukawa and Mattson, 1998) and superior cervical ganglion (Soliven and Albert, 1992) neurons. Modulation of similar channels in DRG neurons could mediate TNF $\alpha$-induced mechanical hypersensitivity. Our results show that TNF $\alpha$ can acutely sensitize TTX-R sodium currents in nociceptors. In theory, this mechanism could account for acute sensitization to both thermal and mechanical stimuli induced by TNF $\alpha$. However, our behavioral results suggest that modulation of TRPV1 is of greater importance than modulation of TTX-R in establishing thermal sensitization after exposure to TNF $\alpha$. Although p38 sensitizes TTX-R and p38 inhibitors prevent mechanical sensitization induced by peripherally applied $\mathrm{TNF} \alpha$, this is only suggestive that modulation of TTX-R by $\mathrm{p} 38$ underlies this sensitization. In future studies, it will be important to address this question more directly by testing whether TNF $\alpha$ can induce mechanical hypersensitivity in mice lacking TTX-R channel subunits.

TNF $\alpha$ exerts its effects on cells via activation of two receptor subtypes: TNFR1 and TNFR2 (Wu, 2004). Previous studies have shown that TNF $\alpha$, TNFR1, and TNFR2 are expressed in adult rat DRG neurons (Shubayev and Myers, 2001; Pollock et al., 2002; Schafers et al., 2003a), and both TNF $\alpha$ and its receptors are upregulated in DRG neurons after chronic constriction injury (Shubayev and Myers, 2001; Schafers et al., 2003a). TNFR1 appears to be particularly important in the pain-sensitizing actions of TNF $\alpha$, because mechanical hypersensitivity induced by exogenous TNF $\alpha$ or by inflammation is reduced in TNFR $1^{-1-}$ mice (Cunha et al., 2005) and antisense knockdown of TNFR1 reduces hyperalgesic priming after inflammation in the rat (Parada et al., 2003). Furthermore, neutralizing antibodies against TNFR1, but not those against TNFR2, reduce thermal and mechanical hypersensitivity after nerve injury (Sommer et al., 1998). Our studies are consistent with these findings in that we demonstrate a critical role for TNFR1, but not TNFR2, in the sensitization of TTX-R by TNF $\alpha$.

TNF receptors activate multiple signaling pathways, including ceramide signaling and activation of several MAPK pathways (Joseph and Levine, 2004; $\mathrm{Wu}, 2004)$. It is now recognized that the p38 MAPK pathway is an important regulator of inflammatory and neuropathic pain (Ji et al., 2002; Kim et al., 2002; Jin et al., 2003; Milligan et al., 2003; Svensson et al., 2003a,b; Inoue et al., 2004; Ji, 2004; Ji and Strichartz, 2004; Obata et al., 2004a,b; Sweitzer et al., 2004a,b; Mizushima et al., 2005; Svensson et al., 2005a,b; Tsuda et al., 2005). Peripheral inflammation results in p38 activation in nociceptive DRG neurons, and p38 participates in the maintenance of inflammatory heat hyperalgesia by increasing TRPV1 expression (Ji et al., 2002). TNF $\alpha$ activates p38 MAPK in cultured DRG neurons (Pollock et al., 2002), and treatment with the TNF $\alpha$ antagonist Etanercept attenuates mechanical hypersensitivity before but not after spinal nerve ligation, an effect that is mimicked by the p38 inhibitor SB203580 (Schafers et al., $2003 \mathrm{~b}$ ). Although these data provide substantial evidence that p38 activation is downstream of TNF $\alpha$ and participates in pain hypersensitivity after inflammation and nerve injury, we do not know the downstream targets of p38 that mediate this sensitization. We show here that p38 activity modulates TTX-R Na ${ }^{+}$ channels in mouse DRG neurons. Furthermore, we show that activation of TNFR1 induces p38 activity in mouse DRG neurons and enhances TTX-R currents in a p38-dependent manner.

We found that p38 inhibitors have effects on basal TTX-R $\mathrm{Na}^{+}$currents in isolated DRG neurons, suggesting that there is basal p38 activity in our preparation. This is perhaps not surprising given that an isolated sensory neuron could be looked at as a rather severe axotomy model, and previous studies have shown that nerve injury leads to enhanced p38 activity in DRG somata (Kim et al., 2002; Jin et al., 2003). Indeed, our results indicate that 
there is a low level of active p38 in unstimulated DRG neurons (Fig. 6). It is interesting to note that previous studies have shown enhanced effects of TNF $\alpha$ when applied to injured and adjacent uninjured neurons in the DRG from nerve-injured rats (Schafers et al., 2003c). It is possible that the effects we are studying in our isolated DRG neurons reflects more the sensitized state observed in nerve-injured animals than it does the naive state. Nevertheless, we do find that peripherally administered TNF $\alpha$ sensitizes naive mice to both thermal and mechanical stimuli by a p38dependent mechanism. Whether the enhanced response to TNF $\alpha$ in nerve-injured animals represents an amplification of the same mechanism seen in naive animals or a different mechanism that is induced by injury remains to be determined.

The studies reported here show that TNF $\alpha$ can directly sensitize nociceptors via a TNFR1- and p38-dependent mechanism. This effect is rapid, beginning $\sim 1$ min after the application of TNF $\alpha$, suggesting a direct action of TNFR1-mediated signaling pathways on TTX-R. Our finding that the potentiation of TTX-R by TNF $\alpha$ was significantly reduced in TNFR $1^{-1-}$ mice relative to wild types suggests a prominent role of TNFR1 in mediating this sensitization. The small potentiation of TTX-R by TNF $\alpha$ in TNFR1 $1^{-/-}$DRG neurons suggests a possible role for a TNFR1independent mechanism in mediating these effects in the TNFR $1^{-1-}$ mice. Although we observed no difference in potentiation of TTX-R in TNFR2 $2^{-/-}$mice compared with wild type, it is possible that, in the context of the TNFR1 knock-out, TNFR2 might play a greater role. Nevertheless, our results show that activation of TNFR1 is the major mechanism by which TNF $\alpha$ modulates TTX-R.

Our findings provide support for the hypothesis that the painsensitizing actions of TNF $\alpha$ are mediated through activation of p38 and suggest that p38 may enhance TTX-R by phosphorylating TTX-R sodium channels or an associated protein. Previously, p38 has been reported to directly modulate other voltage-gated sodium channels. For example, Wittmack et al. (2005) showed that Nav1.6 is modulated by p38 activation, and this effect could be eliminated by mutating a p38 phosphorylation site (Wittmack et al., 2005). In this case, p38 activation resulted in a decrease in current density, whereas our results show that p38 activation leads to an increase in TTX-R currents in DRG neurons. Future studies should endeavor to identify p38 phosphorylation sites in sodium channel subunits to test whether the modulation of TTX-R is mediated by direct phosphorylation of the channel. For example, the published mouse Nav1.8 sequence contains 15 consensus sites for phosphorylation by MAPKs, including p38 (Souslova et al., 1997; Sharrocks et al., 2000). Twelve of these consensus sites are located on predicted intracellular domains, making them possible targets for p38-mediated phosphorylation and modulation of Nav1.8.

Although our results may help explain some of the more rapid pain-sensitizing effects of TNF $\alpha$, it is clear that the overall role of TNF $\alpha$ and related cytokines in mediating various types of chronic pain is much more complex. Many effects of TNF $\alpha$ are mediated by synergistic interactions with other cytokines. For example, only the combination of TNF $\alpha$, interleukin-1 $\beta$, and interleukin- 8 is capable of inducing nociceptive writhing responses after intraperitoneal injection in mice, whereas TNF $\alpha$ alone does not (Ribeiro et al., 2000). Here, we have shown induction of mechanical and thermal hypersensitivity by injection of TNF $\alpha$ alone and effects of TNF $\alpha$ on isolated DRG neurons in vitro, but whether these effects require the concomitant activity of other cytokines is not known. In addition, $\mathrm{TNF} \alpha$ can have TNFR1- and TNFR2-independent effects on cells; in vitro, TNF $\alpha$ can have intrinsic ion channel-forming activity, and this action may underlie some physiological effects of TNF $\alpha$ (Kagan et al., 1992).

TNF $\alpha$ inhibitors are effective for the treatment of inflammatory pain conditions, including rheumatoid arthritis and inflammatory bowel diseases (Hanauer, 2004; Toussirot and Wendling, 2004; Wendling and Toussirot, 2004; Goldblatt and Isenberg, 2005). The agents currently on the market act by sequestering endogenous TNF $\alpha$. Our findings together with previous reports showing amelioration of pain in a variety of models by reducing TNFR1 activation suggest that agents that specifically target TNFR1 or downstream signaling molecules, including p38, could also be effective in specifically targeting pain hypersensitivity induced by TNF $\alpha$.

\section{References}

Bhave G, Gereau RW (2004) Posttranslational mechanisms of peripheral sensitization. J Neurobiol 61:88-106.

Cardenas CG, Del Mar LP, Scroggs RS (1995) Variation in serotonergic inhibition of calcium channel currents in four types of rat sensory neurons differentiated by membrane properties. J Neurophysiol 74:1870-1879.

Cardenas CG, Del Mar LP, Cooper BY, Scroggs R (1997) 5- $\mathrm{HT}_{4}$ receptors couple positively to tetrodotoxin-insensitive sodium channels in a subpopulation of capsaicin-sensitive rat sensory neurons. J Neurosci 17:7181-7189.

Cardenas CG, Mar LP, Vysokanov AV, Arnold PB, Cardenas LM, Surmeier DJ, Scroggs RS (1999) Serotonergic modulation of hyperpolarizationactivated current in acutely isolated rat dorsal root ganglion neurons. J Physiol (Lond) 518:507-523.

Cardenas LM, Cardenas CG, Scroggs RS (2001) 5HT increases excitability of nociceptor-like rat dorsal root ganglion neurons via cAMP-coupled TTX-resistant $\mathrm{Na}^{+}$channels. J Neurophysiol 86:241-248.

Cunha FQ, Poole S, Lorenzetti BB, Ferreira SH (1992) The pivotal role of tumour necrosis factor alpha in the development of inflammatory hyperalgesia. Br J Pharmacol 107:660-664.

Cunha TM, Verri Jr WA, Silva JS, Poole S, Cunha FQ, Ferreira SH (2005) A cascade of cytokines mediates mechanical inflammatory hypernociception in mice. Proc Natl Acad Sci USA 102:1755-1760.

Diem R, Meyer R, Weishaupt JH, Bahr M (2001) Reduction of potassium currents and phosphatidylinositol 3-kinase-dependent AKT phosphorylation by tumor necrosis factor- $\alpha$ rescues axotomized retinal ganglion cells from retrograde cell death in vivo. J Neurosci 21:2058-2066.

Erickson SL, de Sauvage FJ, Kikly K, Carver-Moore K, Pitts-Meek S, Gillett N, Sheehan KCF, Schreiber RD, Goeddel DV, Moore MW (1994) Decreased sensitivity to tumour-necrosis factor but normal T-cell development in TNF receptor-2-deficient mice. Nature 372:560-563.

Furukawa K, Mattson MP (1998) The transcription factor NF-kappaB mediates increases in calcium currents and decreases in NMDA- and AMPA/ kainate-induced currents induced by tumor necrosis factor-alpha in hippocampal neurons. J Neurochem 70:1876-1886.

Goldblatt F, Isenberg DA (2005) New therapies for rheumatoid arthritis. Clin Exp Immunol 140:195-204.

Hanauer SB (2004) Efficacy and safety of tumor necrosis factor antagonists in Crohn's disease: overview of randomized clinical studies. Rev Gastroenterol Disord 4 [Suppl 3]:S18-S24.

Homma Y, Brull SJ, Zhang JM (2002) A comparison of chronic pain behavior following local application of tumor necrosis factor alpha to the normal and mechanically compressed lumbar ganglia in the rat. Pain 95:239-246.

Hu HJ, Bhave G, Gereau RW (2002) Prostaglandin and protein kinase A-dependent modulation of vanilloid receptor function by metabotropic glutamate receptor 5: potential mechanism for thermal hyperalgesia. J Neurosci 22:7444-7452.

Inglis JJ, Nissim A, Lees DM, Hunt SP, Chernajovsky Y, Kidd BL (2005) The differential contribution of tumour necrosis factor to thermal and mechanical hyperalgesia during chronic inflammation. Arthritis Res Ther 7:R807-R816.

Inoue K, Tsuda M, Koizumi S (2004) Chronic pain and microglia: the role of ATP. Novartis Found Symp 261:55-64; discussion 64-67, 149-154. 
Ji RR (2004) Mitogen-activated protein kinases as potential targets for pain killers. Curr Opin Investig Drugs 5:71-75.

Ji RR, Strichartz G (2004) Cell signaling and the genesis of neuropathic pain. Sci STKE 2004:reE14.

Ji RR, Samad TA, Jin SX, Schmoll R, Woolf CJ (2002) p38 MAPK activation by NGF in primary sensory neurons after inflammation increases TRPV1 levels and maintains heat hyperalgesia. Neuron 36:57-68.

Jin SX, Zhuang ZY, Woolf CJ, Ji RR (2003) p38 mitogen-activated protein kinase is activated after a spinal nerve ligation in spinal cord microglia and dorsal root ganglion neurons and contributes to the generation of neuropathic pain. J Neurosci 23:4017-4022.

Joseph EK, Levine JD (2004) Caspase signalling in neuropathic and inflammatory pain in the rat. Eur J Neurosci 20:2896-2902.

Junger H, Sorkin LS (2000) Nociceptive and inflammatory effects of subcutaneous TNFalpha. Pain 85:145-151.

Kagan BL, Baldwin RL, Munoz D, Wisnieski BJ (1992) Formation of ionpermeable channels by tumor necrosis factor-alpha. Science 255:1427-1430.

Kim SY, Bae JC, Kim JY, Lee HL, Lee KM, Kim DS, Cho HJ (2002) Activation of p38 MAP kinase in the rat dorsal root ganglia and spinal cord following peripheral inflammation and nerve injury. NeuroReport 13:2483-2486.

Lee JC, Laydon JT, McDonnell PC, Gallagher TF, Kumar S, Green D, McNulty D, Blumenthal MJ, Keys JR, Landvatter SW, Strickler JE, McLaughlin MM, Siemens IR, Fisher SM, Livi GP, White JR, Adams JL, Young PR (1994) A protein kinase involved in the regulation of inflammatory cytokine biosynthesis. Nature 372:739-746.

Li Y, Ji A, Weihe E, Schafer MK (2004) Cell-specific expression and lipopolysaccharide-induced regulation of tumor necrosis factor $\alpha$ $(\mathrm{TNF} \alpha)$ and TNF receptors in rat dorsal root ganglion. J Neurosci 24:9623-9631.

Lindenlaub T, Teuteberg P, Hartung T, Sommer C (2000) Effects of neutralizing antibodies to TNF-alpha on pain-related behavior and nerve regeneration in mice with chronic constriction injury. Brain Res 866:15-22.

Liu B, Li H, Brull SJ, Zhang JM (2002) Increased sensitivity of sensory neurons to tumor necrosis factor alpha in rats with chronic compression of the lumbar ganglia. J Neurophysiol 88:1393-1399.

Milligan ED, Twining C, Chacur M, Biedenkapp J, O’Connor K, Poole S, Tracey K, Martin D, Maier SF, Watkins LR (2003) Spinal glia and proinflammatory cytokines mediate mirror-image neuropathic pain in rats. J Neurosci 23:1026-1040.

Mizushima T, Obata K, Yamanaka H, Dai Y, Fukuoka T, Tokunaga A, Mashimo T, Noguchi K (2005) Activation of p38 MAPK in primary afferent neurons by noxious stimulation and its involvement in the development of thermal hyperalgesia. Pain 113:51-60.

Nicol GD, Lopshire JC, Pafford CM (1997) Tumor necrosis factor enhances the capsaicin sensitivity of rat sensory neurons. J Neurosci 17:975-982.

Obata K, Yamanaka H, Dai Y, Mizushima T, Fukuoka T, Tokunaga A, Noguchi K (2004a) Differential activation of MAPK in injured and uninjured DRG neurons following chronic constriction injury of the sciatic nerve in rats. Eur J Neurosci 20:2881-2895.

Obata K, Yamanaka H, Kobayashi K, Dai Y, Mizushima T, Katsura H, Fukuoka T, Tokunaga A, Noguchi K (2004b) Role of mitogen-activated protein kinase activation in injured and intact primary afferent neurons for mechanical and heat hypersensitivity after spinal nerve ligation. J Neurosci 24:10211-10222.

Opree A, Kress M (2000) Involvement of the proinflammatory cytokines tumor necrosis factor- $\alpha$, IL- $1 \beta$, and IL- 6 but not IL- 8 in the development of heat hyperalgesia: effects on heat-evoked calcitonin gene-related peptide release from rat skin. J Neurosci 20:6289-6293.

Parada CA, Yeh JJ, Joseph EK, Levine JD (2003) Tumor necrosis factor receptor type-1 in sensory neurons contributes to induction of chronic enhancement of inflammatory hyperalgesia in rat. Eur J Neurosci 17:1847-1852.

Perkins MN, Kelly D (1994) Interleukin-1 beta induceddesArg9bradykinin-mediated thermal hyperalgesia in the rat. Neuropharmacology 33:657-660.

Pfeffer K, Matsuyama T, Kundig TM, Wakeham A, Kishihara K, Shahinian A, Wiegmann K, Ohashi PS, Kronke M, Mak TW (1993) Mice deficient for the $55 \mathrm{kd}$ tumor necrosis factor receptor are resistant to endotoxic shock, yet succumb to L. monocytogenes infection. Cell 73:457-467.

Pollock J, McFarlane SM, Connell MC, Zehavi U, Vandenabeele P, MacEwan
DJ, Scott RH (2002) TNF-alpha receptors simultaneously activate $\mathrm{Ca}^{2+}$ mobilisation and stress kinases in cultured sensory neurones. Neuropharmacology 42:93-106.

Ribeiro RA, Vale ML, Thomazzi SM, Paschoalato ABP, Poole S, Ferreira SH, Cunha FQ (2000) Involvement of resident macrophages and mast cells in the writhing nociceptive response induced by zymosan and acetic acid in mice. Eur J Pharmacol 387:111-118.

Schafers M, Geis C, Brors D, Yaksh TL, Sommer C (2002) Anterograde transport of tumor necrosis factor-alpha in the intact and injured rat sciatic nerve. J Neurosci 22:536-545.

Schafers M, Sorkin LS, Geis C, Shubayev VI (2003a) Spinal nerve ligation induces transient upregulation of tumor necrosis factor receptors 1 and 2 in injured and adjacent uninjured dorsal root ganglia in the rat. Neurosci Lett 347:179-182.

Schafers M, Svensson CI, Sommer C, Sorkin LS (2003b) Tumor necrosis factor- $\alpha$ induces mechanical allodynia after spinal nerve ligation by activation of p38 MAPK in primary sensory neurons. J Neurosci 23:2517-2521.

Schafers M, Lee DH, Brors D, Yaksh TL, Sorkin LS (2003c) Increased sensitivity of injured and adjacent uninjured rat primary sensory neurons to exogenous tumor necrosis factor- $\alpha$ after spinal nerve ligation. J Neurosci 23:3028-3038.

Sharrocks AD, Yang SH, Galanis A (2000) Docking domains and substratespecificity determination for MAP kinases. Trends Biochem Sci 25:448-453.

Shubayev VI, Myers RR (2001) Axonal transport of TNF-alpha in painful neuropathy: distribution of ligand tracer and TNF receptors. J Neuroimmunol 114:48-56.

Soliven B, Albert J (1992) Tumor necrosis factor modulates $\mathrm{Ca}^{2+}$ currents in cultured sympathetic neurons. J Neurosci 12:2665-2671.

Sommer C, Kress M (2004) Recent findings on how proinflammatory cytokines cause pain: peripheral mechanisms in inflammatory and neuropathic hyperalgesia. Neurosci Lett 361:184-187.

Sommer C, Schmidt C, George A (1998) Hyperalgesia in experimental neuropathy is dependent on the TNF receptor 1. Exp Neurol 151:138-142.

Sommer C, Lindenlaub T, Teuteberg P, Schafers M, Hartung T, Toyka KV (2001) Anti-TNF-neutralizing antibodies reduce pain-related behavior in two different mouse models of painful mononeuropathy. Brain Res 913:86-89.

Sorkin LS, Doom CM (2000) Epineurial application of TNF elicits an acute mechanical hyperalgesia in the awake rat. J Peripher Nerv Syst 5:96-100.

Sorkin LS, Xiao WH, Wagner R, Myers RR (1997) Tumour necrosis factoralpha induces ectopic activity in nociceptive primary afferent fibres. Neuroscience 81:255-262.

Souslova VA, Fox M, Wood JN, Akopian AN (1997) Cloning and characterization of a mouse sensory neuron tetrodotoxin-resistant voltage-gated sodium channel gene, Scn10a. Genomics 41:201-209.

Svensson CI, Hua XY, Protter AA, Powell HC, Yaksh TL (2003a) Spinal p38 MAP kinase is necessary for NMDA-induced spinal PGE(2) release and thermal hyperalgesia. NeuroReport 14:1153-1157.

Svensson CI, Marsala M, Westerlund A, Calcutt NA, Campana WM, Freshwater JD, Catalano R, Feng Y, Protter AA, Scott B, Yaksh TL (2003b) Activation of $\mathrm{p} 38$ mitogen-activated protein kinase in spinal microglia is a critical link in inflammation-induced spinal pain processing. J Neurochem 86:1534-1544.

Svensson CI, Schafers M, Jones TL, Powell H, Sorkin LS (2005a) Spinal blockade of TNF blocks spinal nerve ligation-induced increases in spinal P-p38. Neurosci Lett 379:209-213.

Svensson CI, Fitzsimmons B, Azizi S, Powell HC, Hua XY, Yaksh TL (2005b) Spinal p38beta isoform mediates tissue injury-induced hyperalgesia and spinal sensitization. J Neurochem 92:1508-1520.

Sweitzer S, Martin D, DeLeo JA (2001) Intrathecal interleukin-1 receptor antagonist in combination with soluble tumor necrosis factor receptor exhibits an anti-allodynic action in a rat model of neuropathic pain. Neuroscience 103:529-539.

Sweitzer SM, Medicherla S, Almirez R, Dugar S, Chakravarty S, Shumilla JA, Yeomans DC, Protter AA (2004a) Antinociceptive action of a p38alpha MAPK inhibitor, SD-282, in a diabetic neuropathy model. Pain 109:409-419.

Sweitzer SM, Peters MC, Ma JY, Kerr I, Mangadu R, Chakravarty S, Dugar S, Medicherla S, Protter AA, Yeomans DC (2004b) Peripheral and central p38 MAPK mediates capsaicin-induced hyperalgesia. Pain 111:278-285. 
Tchelingerian JL, Quinonero J, Booss J, Jacque C (1993) Localization of TNF alpha and IL-1 alpha immunoreactivities in striatal neurons after surgical injury to the hippocampus. Neuron 10:213-224.

Toussirot E, Wendling D (2004) The use of TNF-alpha blocking agents in rheumatoid arthritis: an overview. Expert Opin Pharmacother 5:581-594.

Tsuda M, Inoue K, Salter MW (2005) Neuropathic pain and spinal microglia: a big problem from molecules in "small" glia. Trends Neurosci 28:101-107.

Wacnik PW, Eikmeier LJ, Simone DA, Wilcox GL, Beitz AJ (2005) Nociceptive characteristics of tumor necrosis factor-alpha in naive and tumorbearing mice. Neuroscience 132:479-491.

Wagner R, Myers RR (1996) Endoneurial injection of TNF-alpha produces neuropathic pain behaviors. NeuroReport 7:2897-2901.

Wagner R, Janjigian M, Myers RR (1998) Anti-inflammatory interleukin-10 therapy in CCI neuropathy decreases thermal hyperalgesia, macrophage recruitment, and endoneurial TNF-alpha expression. Pain 74:35-42.

Wendling D, Toussirot E (2004) Anti-TNF-alpha therapy in ankylosing spondylitis. Expert Opin Pharmacother 5:1497-1507.

Wittmack EK, Rush AM, Hudmon A, Waxman SG, Dib-Hajj SD (2005)
Voltage-gated sodium channel Nav1.6 is modulated by p38 mitogenactivated protein kinase. J Neurosci 25:6621-6630.

Wood JN, Boorman JP, Okuse K, Baker MD (2004a) Voltage-gated sodium channels and pain pathways. J Neurobiol 61:55-71.

Wood JN, Abrahamsen B, Baker MD, Boorman JD, Donier E, Drew LJ, Nassar MA, Okuse K, Seereeram A, Stirling CL, Zhao J (2004b) Ion channel activities implicated in pathological pain. Novartis Found Symp 261:3240, discussion 40-54.

Woolf CJ, Allchorne A, Safieh-Garabedian B, Poole S (1997) Cytokines, nerve growth factor and inflammatory hyperalgesia: the contribution of tumour necrosis factor alpha. Br J Pharmacol 121:417-424.

Wu H (2004) Assembly of post-receptor signaling complexes for the tumor necrosis factor receptor superfamily. Adv Protein Chem 68:225-279.

Yang D, Gereau RW (2004) Group II metabotropic glutamate receptors inhibit cAMP-dependent protein kinase-mediated enhancement of tetrodotoxin-resistant sodium currents in mouse dorsal root ganglion neurons. Neurosci Lett 357:159-162.

Zhang JM, Li H, Liu B, Brull SJ (2002) Acute topical application of tumor necrosis factor alpha evokes protein kinase A-dependent responses in rat sensory neurons. J Neurophysiol 88:1387-1392. 